\title{
Protein turnover in growing pigs. Effects of age and food intake
}

\author{
BY P. J. REEDS, A. CADENHEAD, M. F. FULLER, \\ G. E. LOBLEY AND J. D. MCDONALD \\ Rowett Research Institute, Bucksburn, Aberdeen AB2 $9 S B$
}

(Received 20 June 1979-Accepted 25 October 1979)

\begin{abstract}
1. Measurements were made of the nitrogen and energy balances of pigs of 30,60 and $90 \mathrm{~kg}$ given a conventional diet at various daily rates.

2. Body protein synthesis was estimated from the irreversible loss of leucine from the blood following the infusion of $\left[1^{-14} \mathrm{C}\right]$ leucine, and from the oxidation of the labelled amino acid.

3. Protein synthesis $(\mathrm{g} / \mathrm{d})$ increased by 2.17 for each $1 \mathrm{~g}$ increase in daily protein accretion and by 1.55 for each $I \mathrm{~g}$ increase in daily protein intake.

4. At $30 \mathrm{~kg}$, pigs close to energy equilibrium synthesized $270 \mathrm{~g}$ protein daily compared with $406 \mathrm{~g}$ and $512 \mathrm{~g}$ when their ration supplied twice and three times their maintenance requirement.

5. There was a close correlation between the daily urinary excretion of urea + ammonia and total amino acid catabolism estimated from the catabolism of leucine, but the latter underestimated the observed excretion by $2.5 \mathrm{~g} \mathrm{~N} / \mathrm{d}$.

6. The results imply that protein turnover accounts for only a proportion of the heat production associated with protein deposition.
\end{abstract}

Protein accretion is the resultant of the twin processes of protein synthesis and breakdown, processes which continue throughout life even when growth is zero or negative. Although the amounts of protein which are synthesized and broken down daily eventually become equal when the animal ceases to grow, it is not known whether changes in the rate of protein accretion during growth arise primarily from changes in protein synthesis, in breakdown, or in both, nor is it known, for example, if there is a fixed relationship of one to the other.

Measurements of the rate of protein synthesis in the tissues of pigs at fixed weights have been reported (Garlick et al. 1976; Edmunds et al. 1978; Simon et al. 1978), but there are no reports of the changes which occur as the pig grows. With the exception of measurements made in malnourished children (Picou \& Taylor-Roberts, 1969; Golden et al. 1977, 1978) and in obese adults (Garlick et al. 1978), there is also little information on the relationship between nitrogen balance and protein turnover in the whole body or of the effect of the amount and nature of the diet on this relationship in any species.

It is important to establish the relationship between protein accretion and protein synthesis because the considerable energy required for peptide bond formation contributes to the heat production of the animal and determines how much energy is used in protein synthesis for each unit of protein deposited.

The experiments described in this paper set out to estimate the amounts of protein synthesized in growing pigs and to relate these estimates to simultaneous measurements of $\mathrm{N}$ and energy balance. Studies were made in animals of different weights and ages receiving the same amount of food per unit metabolic weight $\left(\mathrm{kg} \mathrm{W}^{0.75}\right)$ and in animals of a fixed age and body-weight given food at one of three daily rates. 


\section{EXPERIMENTAL}

\section{Design}

This report describes three experiments. In the first, changes in protein and energy metabolism during growth were studied in 18 pigs of 30,60 and $90 \mathrm{~kg}$ body-weight given a single diet at the rate of $90 \mathrm{~g} / \mathrm{kg} \mathrm{W}^{0.75}$ per d. The animals of 60 and $90 \mathrm{~kg}$ body-weight had been studied previously at $30 \mathrm{~kg}$. In the second experiment the effect of food intake was examined by giving the same diet at two levels $\left(90 \mathrm{~g} / \mathrm{kg} \mathrm{W}^{0.75}\right.$ per $\mathrm{d} ; \mathrm{L}$ and $130 \mathrm{~g} / \mathrm{kg} \mathrm{W}^{0.75}$ per d; H) to 12 pigs of the same body-weight (approximately $33 \mathrm{~kg}$ ). In the third experiment pigs, previously fed at levels $\mathrm{H}$ or $\mathrm{L}$ were given the same diet in quantities $\left(45 \mathrm{~g} / \mathrm{kg} \mathrm{W}^{\mathbf{0 . 7 5}} ; \mathrm{M}\right)$ to supply $450 \mathrm{~kJ} \mathrm{ME} / \mathrm{kg} \mathrm{W^{0.75 }}$ per $\mathrm{d}$. Measurements were made immediately before and at 2, 7 and $14 \mathrm{~d}$ after the change in intake.

\section{Animals}

The pigs were the progeny of Large White boars and Large White $\times$ Landrace sows. When they weighed approximately $20 \mathrm{~kg}$ they were prepared for the experiment by the introduction of polyvinyl chloride catheters (NT2; Portex Ltd, Hythe, Kent) under Fluothane anaesthesia. Two catheters were introduced into the aorta, one via each of the saphenous arteries as described by Fuller \& Crofts (1977). One, used for the withdrawal of blood samples, measured $330 \mathrm{~mm}$ from the tip to the point of insertion; the other, used for infusion, measured $250 \mathrm{~mm}$. The free end of each was led under the skin to emerge on the middle of the back. All the animals were kept in metabolism crates after the aortal catheters had been introduced. Urinary catheters were introduced without anaesthesia and the animals were then given an oral, prophylactic dose $(10 \mathrm{~g})$ of Tribrissen (Wellcome Foundation Ltd, London) daily for $3 \mathrm{~d}$.

\section{Procedures}

The same plan was adopted for each study in Expts 1 and 2. From measurements of the rate of gain of body-weight a prediction was made of the day on which the animal would attain the desired body-weight. At $5 \mathrm{~d}$ before the predicted day urine collection was begun and the animal was transferred in its metabolism crate to a sealed wooden chamber measuring internally $\mathrm{I} .8 \times 0.8 \times \mathrm{I} .7 \mathrm{~m}$. Measurements of gas exchange by open-circuit indirect calorimetry were then commenced. Thereafter at least three consecutive measurements were made, each of $24 \mathrm{~h}$ duration. During the last of these measurements the animal was infused with $\left[\mathrm{I}^{14} \mathrm{C}\right]$ leucine.

\section{Diet and feeding}

A single diet was used in all experiments. Its composition is given in Table 1 . Although in a preliminary experiment the effects of feeding this diet once hourly and twice daily were compared (see Reeds et al. 1978), in the experiments reported here all the animals were fed and consumed their food once hourly. They had been fed in this way for at least $14 \mathrm{~d}$ before the start of each experiment. Measurements of the losses of $\mathrm{N}$ and energy in the faeces and urine were made twice in order to determine the digestibility of $\mathrm{N}$ and energy and the metabolizable energy of the diet. These values are also given in Table I.

\section{Measurement of gaseous metabolism}

Outside air was drawn through the chamber at approximately $1.51 / \mathrm{min}$ per $\mathrm{kg}$ body-weight, which resulted in changes of approximately $6 \mathrm{ml} / 1$ in the concentrations of carbon dioxide and oxygen in the chamber. Gas flow through the chamber was measured and both outside 
Table I. Composition $(\mathrm{g} / \mathrm{kg})$ of the diet

Ingredients

$\begin{array}{lc}\text { Ground barley } & 459 \cdot 8 \\ \text { Ground maize } & 101 \cdot 1 \\ \text { Flaked maize } & 101 \cdot 1 \\ \text { Oat flakes } & 101 \cdot \mathrm{I} \\ \text { Sucrose } & 25 \cdot 3 \\ \text { Dried skimmed milk } & 50 \cdot 5 \\ \text { White fish meal } & 75 \cdot 8 \\ \text { Soya-bean meal } & 75 \cdot 8 \\ \text { Salt (sodium chloride) } & 2 \cdot 0 \\ \text { Ground limestone } & 3 \cdot 0 \\ \text { Dicalcium phosphate } & 2 \cdot 0 \\ \text { Vitamin-mineral supplement* } & 2 \cdot 5 \\ \text { Chemical analysis } & \\ \text { Dry matter } & 897 \\ \text { Crude protein (nitrogen } \times 6 \cdot 25) \dagger & 186 \\ \text { Gross energy (MJ/kg) } & 16 \cdot 60 \\ \text { Apparently digestible protein } & 843 \\ \text { Apparently digestible energy } & \\ \text { (g/kg) } & 842 \\ \text { (MJ/kg) } & 13 \cdot 98 \\ \text { Apparently metabolizable energy } & \\ \text { (g/kg) } & 806 \\ \text { (MJ/kg) } & 13 \cdot 38\end{array}$

* Creepvite no. II (Norvite Feed Supplements, Wardhouse, Insch, Aberdeenshire) supplying (/kg diet): retinol $4.5 \mathrm{mg}$, cholecalciferol $40 \mu \mathrm{g}, \alpha$-tocopherol $44 \mathrm{mg}$, copper $0.224 \mathrm{~g}$, selenium 0.0 I I g.

$\dagger$ Containing $(\mathrm{g} / 16 \mathrm{~g} \mathrm{~N})$ : aspartic acid $7 \cdot 609$, threonine $3 \cdot 388$, serine $4 \cdot 505$, glutamic acid $17 \cdot 979$, proline $6 \cdot 758$, glycine $5 \cdot 07 \mathrm{I}$, alanine $4 \cdot 826$, cystine $I \cdot 680$, valine $4 \cdot 669$, methionine $4 \cdot 229$, isoleucine $3 \cdot 890$, leucine $7 \cdot 549$, tyrosine $3 \cdot 726$, phenylalanine $4 \cdot 831$, histidine $2 \cdot 154$, lysine $4 \cdot 950$, arginine $5 \cdot 514$.

air and exhaust air from the chamber were analysed for $\mathrm{O}_{2}$ using a paramagnetic analyser (Servomex, Crowborough, Sussex) and for $\mathrm{CO}_{2}$ using an infra-red analyser (Grubb Parsons Ltd, Newcastle-upon-Tyne). A sample of gas was drawn at a rate of $21 / \mathrm{min}$ through a stainless-steel Cary-Tolbert ionization chamber $(4.21$ internal volume) held at an ionizing potential of $\mathrm{I} 80 \mathrm{~V}$. The output from the ionization chamber was amplified using a Cary Model 40I vibrating-reed electrometer (Varian Associates, Palo Alto, USA). The gas analysers were calibrated once daily with a standard mixture of gases and periodically the $\mathrm{CO}_{2}$ and $\mathrm{O}_{2}$ analysers were calibrated gravimetrically. The ionization chamber was calibrated with ${ }^{14} \mathrm{CO}_{2}$ of known specific radioactivity. The daily rates of $\mathrm{O}_{2}$ consumption and $\mathrm{CO}_{2}$ output were converted to daily heat production using the equation given by Brouwer (I965).

\section{Other analytical methods}

Urine was collected and analysed for total $\mathrm{N}$ as described by Fuller et al. (1977), urea was estimated by the method of Marsh et al. (1965) and ammonia by the method of Fawcett \& Scott (1960). The radioactivity of samples was estimated by scintillation counting using a Packard Tricarb scintillation spectrometer (Model 33I5; Packard Instruments, Downers Grove, Ill., USA). The scintillation fluid was NE 260 (Nuclear Enterprises Ltd, Edinburgh, UK) and the average counting efficiency of ${ }^{14} \mathrm{C}$ was $72 \%$. Corrections for quenching were made by adding a constant amount of $\mathrm{pH} 4 \cdot 2$ buffer to each vial and calibrating against a standard prepared under the same conditions. 


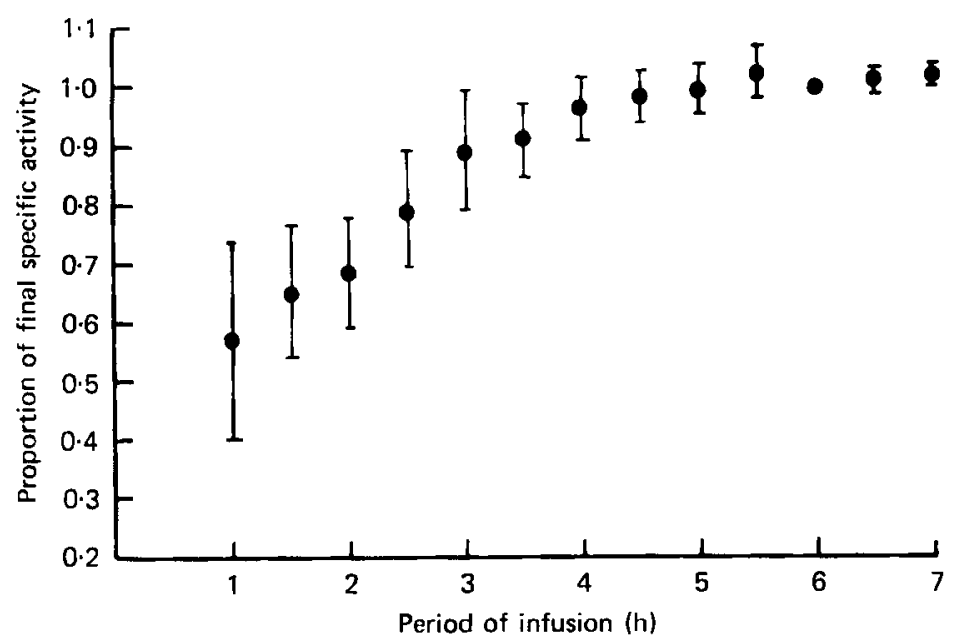

Fig. I. The specific radioactivity of ${ }^{14} \mathrm{CO}_{2}$ during the infusion of $\left[1-{ }^{14} \mathrm{C}\right]$ leucine in growing pigs. The points are plotted from the values obtained in $30 \mathrm{~kg}$ pigs fed at $90 \mathrm{~g} / \mathrm{kg} \mathrm{W}$..75 per d and are expressed as a proportion of the value after $6 \mathrm{~h}$ of infusion. Points are mean values with their standard errors represented by vertical bars, for six values. For details of dietary treatment, see p. 446 .

\section{Measurement of protein synthesis}

A solution containing $2 \mu \mathrm{Ci}\left[{ }^{1-14} \mathrm{C}\right]$ leucine $/ \mathrm{ml}$ in physiological saline (9 g sodium chloride/l) was infused at a rate of $3.45 \mathrm{ml} / \mathrm{h}$ for a minimum of $5.5 \mathrm{~h}$. $\mathrm{L}-\left[\mathrm{I}-{ }^{14} \mathrm{C}\right]$ leucine ( $\mathrm{mCi} / \mathrm{mmol}$ ) was obtained from the Radiochemical Centre, Amersham, Bucks and checked for purity by ion-exchange chromatography. After $4 \mathrm{~h}$ of infusion a minimum of four samples of blood ( $10 \mathrm{ml}$ ) were removed at 30 min intervals, mixed with $\mathrm{I} \cdot 25 \mu \mathrm{mol} \mathrm{L}$-norleucine and frozen at $-20^{\circ}$ until they were prepared for analysis by the method described by Nicholas et al. (1977). Free leucine so extracted from whole blood was separated and analysed using an amino acid analyser (Locarte Co. Ltd, London) in $0.2 \mathrm{M}$-sodium buffer, $\mathrm{pH}_{4.2 \mathrm{I}}$ at a flow rate of approximately $30 \mathrm{ml} / \mathrm{h}$.

The specific radioactivity (SR) of free leucine in the blood reached a constant value by $3 \mathrm{~h}$ of infusion and over twenty-nine infusions the coefficient of variation of the SR at plateau was $4.8 \%$ with no detectable time trend. The $\mathrm{SR}$ of $\mathrm{CO}_{2}$ attained a plateau $30-60 \mathrm{~min}$ later than blood leucine (see Fig. 1).

In the present experiments the total amount of protein synthesized in the body was calculated from the apparent irreversible loss (flux; Q) of blood leucine on the assumption that this loss occurs only by incorporation of the amino acid into protein and by catabolism of the amino acid. $Q$ was calculated as:

$$
\mathrm{Q}(\mathrm{mmol} / \mathrm{h})=\frac{\text { rate of infusion (disintegrations } / \mathrm{min} \text { per } \mathrm{h} \text { ) }}{\mathrm{SR} \text { of blood leucine (disintegrations } / \mathrm{min} \text { per } \mathrm{mmol})}
$$

and protein synthesis $(\mathrm{S})$ as $\mathrm{Q}-\mathrm{Q} . f_{o}$ where $f_{o}$ is the proportion of the dose of radioactivity excreted as $\mathrm{CO}_{2}$.

The values were converted to $\mathrm{g} \mathrm{N} / \mathrm{d}$ by multiplying by

$$
(24 \times 131) /\left(0.066 \times 10^{3} \times 6.25\right)=7.62 \text {, }
$$

where $13 \mathrm{I}$ is the molecular weight of leucine, 0.066 is the average leucine content $(\mathrm{g} / \mathrm{g})$ in 


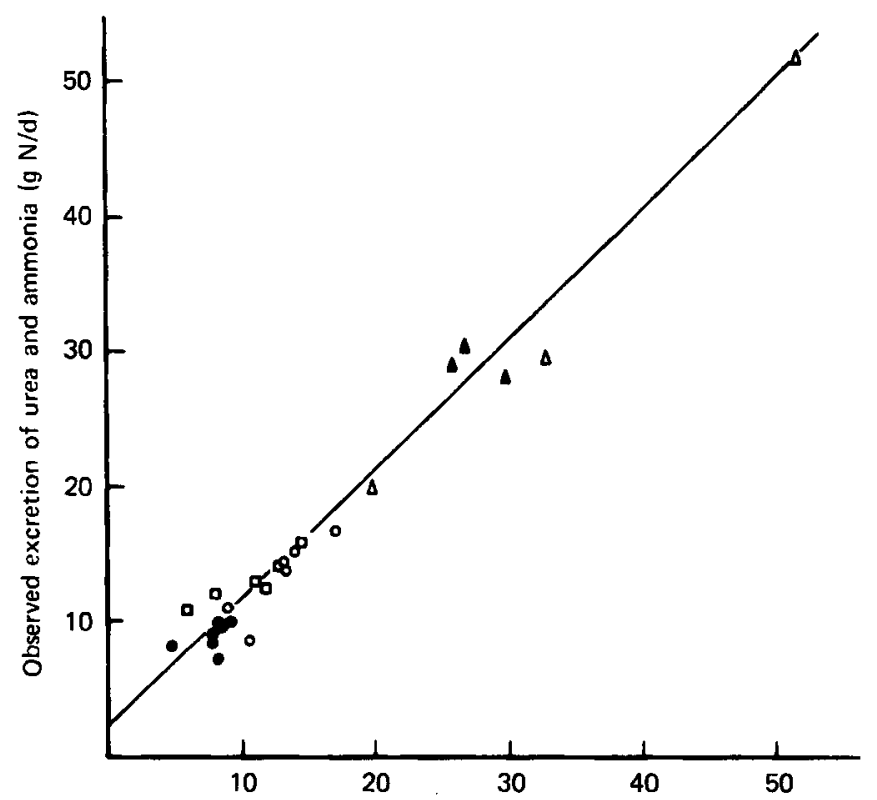

Excretion of urea and ammonia calculated from leucine oxidation (g $\mathrm{N} / \mathrm{d}$ )

Fig. 2. The relationship between the excretion of urea and ammonia (g nitrogen/d) and that predicted from the catabolism of leucine in growing pigs. The points are the values obtained in $30 \mathrm{~kg}$ pigs fed a standard diet at $45(0), 90(\square)$ and $130(0) \mathrm{g} / \mathrm{kg} \mathrm{W} \mathrm{W}^{0.75}$ per $\mathrm{d}$ and for $60 \mathrm{~kg}(\mathbf{A})$ and $90 \mathrm{~kg}(\triangle)$ pigs fed at $90 \mathrm{~g} / \mathrm{kg} \mathrm{W}^{0.75}$ per d. For details of dietary treatments, see p. 446 and for the calculation p. 449 .

The equation of the best line is $y=I \cdot 01 x+2 \cdot 4 \mathrm{I}$, where $y$ is the measured excretion of urea and ammonia and $x$ the calculated value. $n 26 ; r 0.980 ; P<0.001$.

pig carcass protein (Williams et al. 1954 ) and 6.25 the reciprocal of the average $\mathrm{N}$ content of body protein ( $0.16 \mathrm{~g} / \mathrm{g}$; Franke \& Weniger, 1958).

The use of values of blood leucine SR obtained over $2 \mathrm{~h}$ in the calculation of total protein synthesis over a whole day depends upon the maintenance of a quasi-steady-state of leucine intake and metabolism, both during the infusion and for several days before. The maintenance of an approximately constant intake of protein is best achieved by feeding the animals once hourly and it is critical for the extrapolation that the pigs consume all the food offered to them during the infusion. It was this requirement which led to the paucity of information on pigs at higher body-weights as the intake of the older animals became increasingly irregular, particularly when they were in the respiration chamber, and the decision was made to publish values only from pigs which had maintained a regular intake of food for the whole of the study period.

Central to the method is the assumption that the SR of the compartments from which protein is synthesized and from which leucine is catabolized is the same as that of the free leucine in the blood. There is considerable controversy over this assumption and Waterlow et al. (1978), having reviewed the evidence, concluded that total body protein synthesis calculated from the flux of a single amino acid is probably underestimated.

One, at least partial, test of the general validity of the method can be made by comparison of the excretion of urea and ammonia with that calculated from the catabolism of leucine measured during the infusion (i.e. $Q \cdot f_{0} \times 7 \cdot 62$ ). This prediction is based on assumptions additional to those mentioned previously: i.e. (1) that the rate of excretion of ${ }^{14} \mathrm{CO}_{2}$ is an 
Table 2. Expts I and 2. Protein metabolism of pigs of approximately 30, 60 and $90 \mathrm{~kg}$ bodyweight given a standard diet at rates of $90(L)$ or $130(H) \mathrm{g} / \mathrm{kg}$ metabolic body-weight per d

\begin{tabular}{|c|c|c|c|c|c|}
\hline 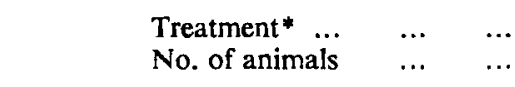 & $\begin{array}{c}30 \mathrm{H} \\
6\end{array}$ & $\begin{array}{c}30 \mathrm{~L} \\
6\end{array}$ & $\begin{array}{c}60 \mathrm{~L} \\
4\end{array}$ & $\begin{array}{c}90 \mathrm{~L} \\
2\end{array}$ & Residual sD \\
\hline Mean body-weight $(\mathrm{kg})$ & 34.5 & $32 \cdot 9$ & 62.5 & $94 \cdot 7$ & - \\
\hline Digested nitrogen $(\mathrm{g} / \mathrm{d})$ & $39 \cdot 8$ & $28 \cdot 4$ & $48 \cdot 5$ & $56 \cdot 0$ & - \\
\hline Metabolizable energy (MJ/d) & $21 \cdot 5$ & $15 \cdot 3$ & $26 \cdot 5$ & $30 \cdot 6$ & - \\
\hline Daily $N$ balance $(\mathrm{g})$ & $24 \cdot 8$ & 14.4 & $15 \cdot 3$ & $\begin{array}{c}8 \cdot 0 \\
(3 ; 13) \dagger\end{array}$ & $\begin{array}{c}2 \cdot 9 \\
(2 \cdot 6) \ddagger\end{array}$ \\
\hline Daily energy balance (MJ) & $10 \cdot 0$ & $5 \cdot 0$ & 7.0 & $7 \cdot 7$ & $1 \cdot 4$ \\
\hline Protein synthesis $(\mathrm{g} \mathrm{N} / \mathrm{d})$ & 82 & 65 & 97 & 107 & 13 \\
\hline Protein breakdown (g N/d) & 55 & 50 & 82 & 97 & 12 \\
\hline Leucine oxidation ( $\mu \mathrm{Ci} / \mathrm{mCi}$ infused) & 118 & I 56 & 206 & 309 & 50 \\
\hline Total amino acid catabolism $(\mathrm{g} \mathrm{N} / \mathrm{d})$ & II 2 & 10.7 & $25 \cdot 6$ & $42 \cdot 5$ & $5 \cdot 2$ \\
\hline Urea + ammonia ( $\mathrm{g} \mathrm{N} / \mathrm{d})$ & 12.6 & 13.4 & $29 \cdot 2$ & $40 \cdot 4$ & $4 \cdot 8$ \\
\hline Blood leucine concentration $(\mathrm{nmol} / \mathrm{ml})$ & 290 & 288 & 257 & 271 & 34 \\
\hline
\end{tabular}

accurate measure of the rate of catabolism of leucine and (2) that the proportion of leucine in body protein is the same as the contribution of leucine to the total amino- $\mathrm{N}$ flux and that the dietary mixture of amino acids is close to that of the requirement.

The calculated and the measured values of the excretion of urea and ammonia- $\mathrm{N}$ are shown in Tables 2 and 3 and the correlation between the two values is highly significant (Fig. $2 ; r 0.983, P<0.001$ ), the slope of the line being 1.01 . There is, however, a statistically significant intercept showing that the calculated value is a fixed underestimate $(2.4 \mathrm{~g} \mathrm{~N} / \mathrm{d})$ of the true value. Golden \& Waterlow (1978), who have carried out a similar comparison of predicted and measured losses of leucine in elderly humans at zero $\mathrm{N}$ balance, have also concluded that the SR of blood leucine underestimates the true flux of leucine by approximately $18 \%$.

Whilst it is possible that the errors associated with each of the assumptions may fortuitously cancel each other, the close correlation shown in Fig. 2 indicates that the method forms a firm basis for comparative measurements. Furthermore, the practical simplicity of a method based upon measurements made on blood allows sequential studies to be made which would be difficult to carry out in large animals by methods which involve the excision and analysis of tissues.

\section{RESULTS AND DISCUSSION}

\section{Body-weight, feed intake and protein metabolism}

The results of Expts $I$ and 2 are shown in Table 2. As the animals grew larger there was a highly significant increase $(P<0.0 \mathrm{I})$ in total protein synthesis. Total protein breakdown, estimated (Picou \& Taylor-Roberts, 1969) as the difference between $Q$ and protein intake also increased. Expressed as $\mathrm{g} \mathrm{N} / \mathrm{kg}^{0.75}$ per $\mathrm{d}$ protein synthesis fell progressively as the animals grew, being significantly $(P<0.02)$ lower at $90 \mathrm{~kg}(3.52)$ than at $60 \mathrm{~kg}(4.36)$ and $30 \mathrm{~kg}(4 \cdot 73)$. In contrast protein breakdown per $\mathrm{kg} \mathrm{W}^{\mathbf{0 . 7 5}}$ changed little with body-weight being $3.44,3.69$ and 3.26 at 30,60 and $90 \mathrm{~kg}$ respectively.

The interpretation of the results relating body-weight to body protein synthesis is complicated by the fact that, as the animals grew, their daily intakes of energy and protein increased. Fig. 3 demonstrates that whether protein intake was increased with body-weight 


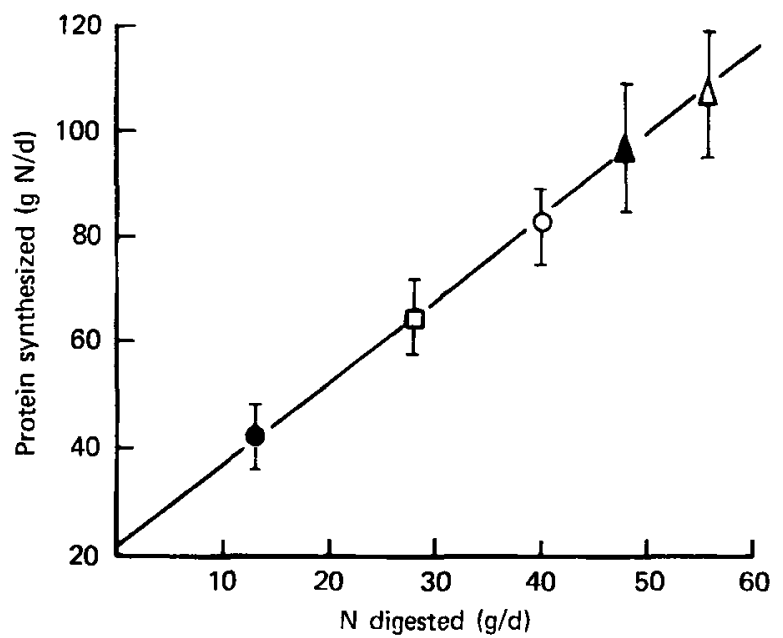

Fig. 3. The relationship between the intake of digestible nitrogen ( $\mathrm{g} \mathrm{N} / \mathrm{d})$ and total body protein synthesis $(\mathrm{g} \mathrm{N} / \mathrm{d})$ measured from the flux of leucine in growing pigs. Points are mean values with their standard deviations indicated by vertical bars, for values obtained in $30 \mathrm{~kg}$ pigs given the same diet at $45(0), 90(\square)$ and $130(O) \mathrm{g} / \mathrm{kg} \mathrm{W0.75}$ per $\mathrm{d}$ and in $60 \mathrm{~kg}(\Delta)$ and $90 \mathrm{~kg}(\triangle)$ pigs fed at $90 \mathrm{~g} / \mathrm{kg} \mathrm{W0.75}$ per d. For details of dietary treatments, see p. 446.

The equation of the best line is $y=1 \cdot 55 x+22 \cdot 1$, where $y$ is protein synthesis and $x$ is the N intake; $n 26 ; r 0.948 ; P<0.001$.

(Expt 1) or independently of body-weight (Expts 2 and 3) there was a highly significant correlation $(r 0.948 ; P<0.001)$ between total protein intake and total protein synthesis. It appeared that between the five groups of animals an increase in protein intake of $\mathrm{I} \mathrm{N} / \mathrm{d}$ was associated with an increase in protein synthesis of $1.55 \mathrm{~g} \mathrm{~N} / \mathrm{d}$. The question remains though whether the changes in protein synthesis, particularly those observed in Expts 2 and 3, are causally related to protein intake, energy intake or both.

Results of measurements made with $\left.{ }^{15} \mathrm{~N}\right]$ glycine (Picou \& Taylor-Roberts, 1969; Golden et al. 1977, 1978) in malnourished children receiving a fixed intake of energy (approximately $500 \mathrm{~kJ} / \mathrm{kg}$ body-weight per d) suggest that protein synthesis in the whole body is insensitive to an increase in the intake of protein. Even when the children were growing rapidly, body protein synthesis was more closely correlated with the intake of energy than with that of protein (Golden et al. 1977; Waterlow et al. 1978). Recent results obtained for older children recovering from cystic fibrosis confirm the response of protein synthesis to dietary energy (Adeniyi-Jones et al. 1979). The situation in adults may be different as Garlick et al. (1978) and Garlick (1979) have found that in obese adults protein synthesis is relatively insensitive to changes in energy supply but changes markedly when the intake of protein is altered; a similar result with respect to the intake of protein has been obtained with young adults (Motil et al. 1979). In contrast Tschudy et al. (1959) in their study of one adult, could detect changes in protein synthesis only when the intakes of both energy and protein were altered. The differences in the results may be due to the age of the subject but it is also possible that the magnitude of the changes in protein synthesis may depend upon the basal levels of energy and protein to which experimental supplements are added. For example, in growing pigs and rats there is an interaction between the initial level of nutrient intake and the response of $\mathrm{N}$ balance to changes in protein and energy intake (Fuller et al. 1973; Fuller \& Crofts, 1977). 
Table 3. Expt 3. Protein metabolism of pigs of approximately $30 \mathrm{~kg}$ body-weight given a standard diet of the rate of either $90(\mathrm{~L})$ or $130(\mathrm{H}) \mathrm{g} / \mathrm{kg}$ metabolic body-weight perd and then at $45(M) \mathrm{g} / \mathrm{kg}$ metabolic body-weight per $d$

Treatment* ... $\quad \ldots \quad \ldots \quad 30 \mathrm{H}$

No. of animals

Mean body-weight $(\mathrm{kg})$

Digested nitrogen $(\mathrm{g} / \mathrm{d})$

Metabolizable energy (MJ/d)

Daily $\mathbf{N}$ balance $(\mathrm{g} / \mathrm{d})$

Energy balance (MJ/d)

Protein synthesis $(\mathrm{g} \mathrm{N} / \mathrm{d})$

Protein breakdown (g N/d)

Leucine oxidation $(\mu \mathrm{Ci} / \mathrm{mCi}$ infused)

Total amino acid catabolism ( $\mathrm{g} \mathrm{N} / \mathrm{d}$ )

Urea + ammonia excretion ( $\mathrm{g} \mathrm{N} / \mathrm{d}$ )
30L

$30 \cdot 5$

$40 \cdot 2$

$22 \cdot 3$

$26 \cdot 2$

$11 \cdot 7$

80

51

77

8.6

13.0
2

$30 L$
2
$31 \cdot 0$
$29 \cdot 8$
$15 \cdot 5$
$15 \cdot 4$
$6 \cdot 8$
66
50
100
$9 \cdot 1$
$12 \cdot 0$

I $2 \cdot 0$

\begin{tabular}{ccc}
\hline $2 \mathrm{~d}$ & $7 \mathrm{~d}$ & $14 \mathrm{~d}$ \\
4 & 4 & 4 \\
- & - & - \\
13 & 13 & 13 \\
7.4 & 7.4 & 7.4 \\
2.4 & 4.8 & 3.8 \\
-0.3 & +0.3 & +0.4 \\
51 & 48 & 43 \\
44 & 43 & 38 \\
52 & 128 & 162 \\
2.8 & 7.3 & 8.2 \\
9.4 & 8.4 & 9.2
\end{tabular}

$9 \cdot 2$

* $30 \mathrm{M}, 30 \mathrm{~kg}$ animals fed at level $\mathrm{M}$ for 2, 4 and $7 \mathrm{~d}$. For details of diets and treatments, see p. 446 and Table I.

Nevertheless there is a lack of information upon changes in protein turnover following independent changes in the intake of energy and protein over a 'normal' range in growing animals which have not had a history of nutritional deprivation.

\section{Protein synthesis and protein deposition}

The $\mathrm{N}$ balance of the pigs of 30 and $60 \mathrm{~kg}$ body-weight and fed at level L (groups $30 \mathrm{~L}$ and $60 \mathrm{~L}$ respectively) were very similar and whilst the mean value for the $90 \mathrm{~kg}$ pigs fed at level $\mathrm{L}$ (group 9oL) was lower the two individual values were very different ( 3 and $13 \mathrm{~g} \mathrm{~N} / \mathrm{d}$ ). Nevertheless, over the range of body-weights covered by Expt I, protein intake increased by a factor of 2.2 and hence a progressively lower proportion of the protein intake was deposited as the animals aged. As protein intake remained an essentially constant proportion of total amino-N flux $(0.37,0.40$ and 0.38 in groups $30 \mathrm{~L}, 60 \mathrm{~L}$ and $90 \mathrm{~L}$ respectively) it was to be expected that leucine catabolism, as a proportion of the flux of leucine $\left(f_{o}\right)$, was significantly greater $(P<0.0 \mathrm{I})$ in the heavier animals. This increase was not merely a consequence of their greater food intake, for in the animals of $30 \mathrm{~kg}$ body-weight there was a significant reduction in $f_{o}(P<0.05)$ with an increase in food intake; although it should be noted that there was a short-term reduction in $f_{o}$ following an abrupt reduction in intake (30M day 2; Table 3). Presumably the change in leucine oxidation with increasing intake is a response to a difference in the intake of dietary energy for it has been found that at constant energy intake the catabolism of leucine in man (Garlick 1979; Motil et al. 1979) and of valine (Reeds, 1974) and leucine (Sketcher et al. 1974) in the rat is directly proportional to the intake of protein.

One of the major aims of the present experiments was to investigate the relationship between protein deposition and protein synthesis. In Expt I protein synthesis increased with little or no increase in total protein deposition whilst in Expt 2 both processes increased in concert. The efficiency of protein deposition may be expressed as the proportion of total body protein synthesis (S) which is deposited (D). As the animals grew larger D:S decreased, being $0.22,0.16$ and 0.08 in groups $30 \mathrm{~L}, 60 \mathrm{~L}$ and $90 \mathrm{~L}$ respectively. In Expt 2 where both $\mathrm{S}$ and $\mathrm{D}$ increased, $\mathrm{D}: \mathrm{S}$ in $30 \mathrm{~kg}$ pigs fed at level $\mathrm{H}(0.30 \pm 0.049$ (SD)) was significantly $(P<0.05)$ higher than in $30 \mathrm{~kg}$ pigs fed at level $\mathrm{L}(0.22 \pm 0.06 \mathrm{r})$. 


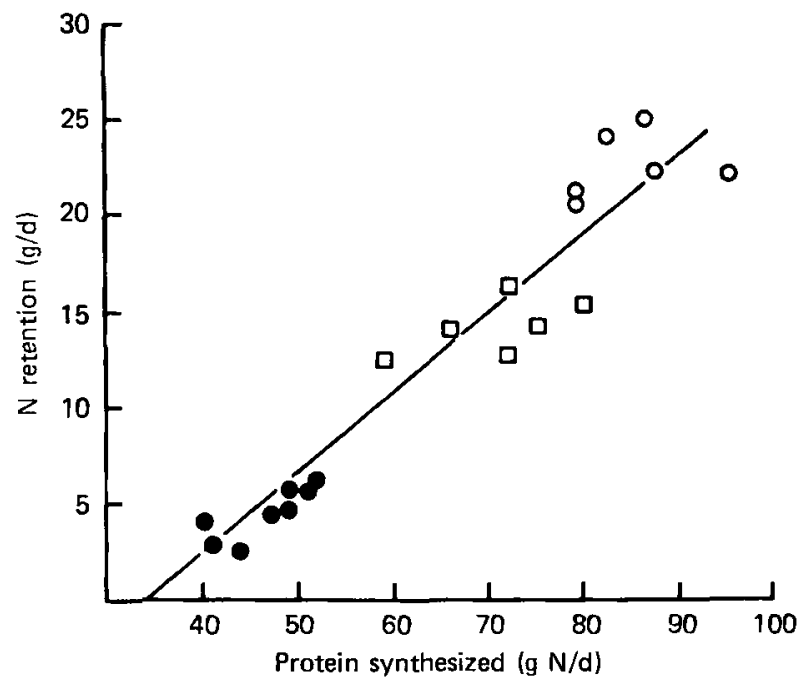

Fig. 4. The relationship between nitrogen balance $(\mathrm{g} \mathrm{N} / \mathrm{d})$ and total body protein synthesis ( $\mathrm{g} \mathrm{N} / \mathrm{d}$ ) measured from the flux of leucine in growing pigs. The points are values obtained in $30 \mathrm{~kg}$ pigs given the same diet at 45 (for 7 and $14 \mathrm{~d}, 0$ ); $90(\square)$ and $130(\mathrm{O}) \mathrm{g} / \mathrm{kg} \mathrm{W}^{0.75}$ per d. For details of dietary treatments, see p. 446.

The equation of the best line is $y=0.46 x-15.6$, where $y$ is daily $\mathrm{N}$ balance and $x$ is protein synthesis; $n 20 ; r 0.903 ; P<0.001$.

The results of Expt 2 can be more fully interpreted if the metabolism of the animal when it is not growing is considered. Whilst the physiological significance of results obtained in such animals is debatable, the fact remains that the relationship between protein synthesis and $\mathrm{N}$ balance above $\mathrm{N}$ equilibrium (Fig. 4) is linear and at $\mathrm{N}$ equilibrium body protein synthesis is $34 \mathrm{~g} \mathrm{~N} / \mathrm{d}$. Thus body protein synthesis in animals of $30 \mathrm{~kg}$ body-weight at near zero energy retention ( $30 \mathrm{~kg}$ pigs fed at level M, day $\mathrm{I}_{4}$ ) is still half that found in animals of the same weight given three times as much food. Even when the plot for $\mathrm{N}$ retention $v$. protein synthesized (Fig. 4) is extrapolated to zero $\mathrm{N}$ retention total body protein synthesis is still apparently $41 \%$ of that found at the highest food intake. The relationship, which is illustrated in Fig. 4, suggests that when protein synthesis and protein deposition are altered by varying daily food intake at a fixed body-weight then each unit increase in protein deposition is associated with an increase of $2 \cdot 17$ in total protein synthesis and hence, presumably, an increase of 1.17 in the breakdown of body protein. Clearly, the greater the deviation of protein synthesis and deposition from the basal state then the smaller is the proportion of 'maintenance' protein synthesis in the total and hence D:S becomes larger.

The present experiments did not include measurements in heavier animals given small amounts of food, so no comparable estimate can be made of total body protein synthesis at either $\mathbf{N}$ or energy equilibrium in the older pigs. However, inter-species comparisons of adult animals (Garlick, 1979) or of growing animals restricted to zero energy retention (MacRae \& Reeds, I979) suggest that there is a fixed relationship between protein synthesis and $\mathrm{W}^{0.75}$. If this constancy is assumed and the rate of protein synthesis $/ \mathrm{kg} \mathrm{W}^{0.75}$ for the $30 \mathrm{~kg}$ pigs at $\mathrm{N}$ equilibrium ( $34 \mathrm{~g} \mathrm{~N} / \mathrm{d}$ ) is applied to those of higher body-weights then for the heavier animals, after 'maintenance' requirements had been met, the value for $D: S$ would fall to 0.36 at $60 \mathrm{~kg}$ and $0.3 \mathrm{I}$ at $90 \mathrm{~kg}$ compared with the value of 0.46 at $30 \mathrm{~kg}$ bodyweight. 


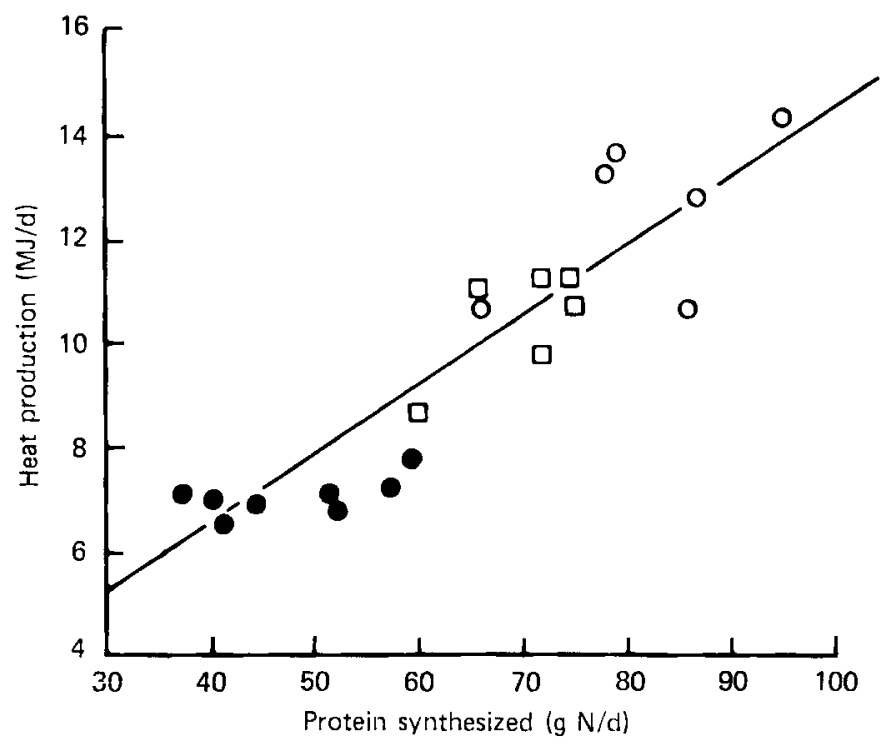

Fig. 5. The relationship between total heat production $(\mathrm{MJ} / \mathrm{d})$ and total body protein synthesis $(\mathrm{g} \mathrm{N} / \mathrm{d})$ in growing pigs. The points are values obtained in $30 \mathrm{~kg}$ pigs given the same diet at 45 (for 7 and $14 \mathrm{~d}, 0$ ); $90(\square)$ and $130(\mathrm{O}) \mathrm{g} / \mathrm{kg} \mathrm{W}^{0.75}$ per $\mathrm{d}$. For details of dietary treatment see p. 446.

The equation of the best line is $y=0.133 x+1 \cdot 22$, where $y$ is heat production and $x$ is protein synthesis: $n 20 ; r 0.893 ; P<0.01$.

\section{Heat production and protein synthesis}

Multiple regression analysis of the relationship between heat production, protein deposition and fat deposition (Close \& Mount, 1971; Kielanowski, 1976) has suggested that heat production is closely related to protein deposition and this has been taken to imply that the process of protein deposition is energetically inefficient. The fact that protein synthesis greatly exceeds protein deposition and requires a considerable input of energy has been suggested as an explanation for the apparently high energy cost of protein deposition (Buttery \& Boorman, 1976; Kielanowski, 1976).

Most authors (for example Millward et al. 1976; Webster et al. 1978; Waterlow et al. I978) have assumed that the energy cost of protein synthesis is $4.5 \mathrm{~kJ} / \mathrm{g}$ (i.e. the synthesis of each peptide bond requires $5 \mathrm{~mol}$ ATP and the synthesis of $1 \mathrm{~mol}$ ATP requires $85 \mathrm{~kJ}$ metabolizable energy). In the animals in Expts 2 and 3 it appeared that an increase of $1 \mathrm{~g} / \mathrm{d}$ in $\mathrm{N}$ balance required protein synthesis of $2.17 \mathrm{~g} \mathrm{~N} / \mathrm{d}$. Using these values and taking the metabolizable energy of protein as $23.5 \mathrm{~kJ} / \mathrm{g}$ gives a value for the energetic efficiency of protein deposition $\left(k_{p}\right)$ of $0.7 \mathrm{l}$. This is much higher than the values derived by others (for example, Pullar \& Webster, 1977: Close, 1978) from the close relationship between heat production and protein deposition, a relationship which in its turn implies a close correlation between heat production and protein synthesis. A close relationship between heat production and protein synthesis has been observed in Zucker rats (Webster et al. 1978) and is also seen in the results from the present experiments (Fig. 5). The results suggest a heat increment of $2 \mathrm{I} \cdot 5 \mathrm{~kJ} / \mathrm{g}$ protein synthesized, implying that on this basis $k_{p}$ would be approximately 0.46 .

Clearly the two values of $k_{n}$ are incompatible. Either the conventional estimate of the ATP requirement for protein synthesis is too low by a factor of 7 or there are other processes, 
such as the pumping of sodium and potassium, which not only account for a significant proportion of the energy requirement of the animal but also correlate very closely with protein synthesis. The identification of these processes is of great importance for the expansion of our understanding of the energy exchanges of animals.

\section{REFERENCES}

Adeniyi-Jones, S., Suskind, R., Polombo, J., Pena-Cruz, V. \& Khaw, K. T. (1979). Fedn Proc. Fedn Am. Socs exp. Biol. 38, 25 I Abstr.

Brouwer, E. (1965). Publs Eur. Ass. Anim. Prod. no. 11, p. 441.

Buttery, P. J. \& Boorman, K. N. (1976). Publs Eur. Ass. Anim. Prod. no. 16, p. 197.

Close, W. H. (1978). Br. J. Nutr. 40, 433.

Close, W. H. \& Mount, L. E. (197I). Proc. Nutr. Soc. 30, 33A.

Edmunds, B. K., Buttery, P. J. \& Fisher, C. (1978). Proc. Nutr. Soc. 37, 32 A.

Fawcett, J. K. \& Scott, J. E. (1960). J. clin. Path. 13, I56.

Franke, E.-R. \& Weniger, J. H. (1958). Arch. Tierernähr. 8, 81.

Fuller, M. F., Boyne, A. W., Atkinson, T. \& Smart, R. (1973). Nutr. Rep. int. 7, 175.

Fuller, M. F. \& Crofts, R. M. J. (1977). Br. J. Nutr. 38, 479.

Fuller, M. F., Weekes, T. E. C., Cadenhead, A. \& Bruce, J. B. (1977). Br. J. Nutr. 38, 489.

Garlick, P. J. (1979). In Protein Deposition in Animals [P. J. Buttery and D. B. Lindsay, editors]. London: Butterworths. (In the Press.)

Garlick, P. J., Burk, T. L. \& Swick, R. W. (1976). Am. J. Physiol. 230, I 108.

Garlick, P. J., Clugston, G. A. \& Waterlow, J. C. (1978). Proc. Nutr. Soc. 37, 22 A.

Golden, M. H. N. \& Waterlow, J. C. (1978). Clin. Sci. mol. Med. 53, 277.

Golden, M. H. N., Waterlow, J. C. \& Picou, D. (1977). Am. J. clin. Nutr. 30, 1345.

Golden, M. H. N., Waterlow, J. C. \& Picou, D. (1978). Clin. Sci. mol. Med. 53, 473.

Kielanowski, J. ( 1976). Publs Eur. Ass. Anim. Proc. no. 16, p. 207.

MacRae, J. C. \& Reeds, P. J. (1979). In Protein Deposition in Animals [P. J. Buttery and D. B. Lindsay, editors]. London: Butterworths. (In the Press.)

Marsh, W. H., Fingerhut, B. \& Miller, H. (Is 65). Clin. Chem. 2, 624.

Millward, D. J., Garlick, P. J. \& Reeds, P. J. (1976). Proc. Nutr. Soc. 35, 339.

Motil, K. J., Matthews, D., Rohrbaugh, D., Brier, D., Burke, J. F. \& Young, V. R. (I979). Fedn Proc. Fedn Am. Socs exp. Biol. 38, 2533 Abstr.

Nicholas, G. A., Lobley, G. E. \& Harris, C. I. (1977). Br. J. Nutr. 38, 1.

Picou, D. \& Taylor-Roberts, T. (1969). Clin. Sci. mol. Med. 36, 283.

Pullar, J. D. \& Webster, A. J. F. (1977). Br. J. Nutr. 35, 355.

Reeds, P. J. ( 1974). Br. J. Nutr. 31, 259.

Reeds, P. J., Fuller, M. F., Lobley, G. E., Cadenhead, A. \& McDonald, J. D. (1978). Proc. Nutr. Soc. 37, I06A.

Simon, O., Münchmeyer, R., Bergner, H., Zebrowska, T. \& Buraczewska, L. (1978). Br. J. Nutr. 40, 243.

Sketcher, R. D., Fern, E. B. \& James, W. P. T. ( 1 974). Br. J. Nutr. 3I, 333.

Tschudy, D., Bacchus, H., Weissinan, S., Watkin, D. H., Eubanks, M. \& White, J. (1959). J. clin. Invest. $3^{8}$, 892 .

Waterlow, J. C., Garlick, P. J. \& Millward, D. J. (1978). Protein Turnover in Mammalian Tissues and in the Whole Body. Amsterdam: North Holland.

Webster, A. J. F., Lobley, G. E., Reeds, P. J. \& Pullar, J. D. (1978). Proc. Nutr. Soc. 37, 2 A.

Williams, H. H., Curtin, L. V., Abraham, J., Loosli, J. K. \& Maynard, L. A. (1954). J. biol. Chem. $205,277$. 